\title{
Diversity of non-symbiotic nitrogen-fixing bacteria and their potential in andisols affected by the eruption of Mount Sinabung, North Sumatra, Indonesia
}

\author{
MARIANI SEMBIRING ${ }^{\boldsymbol{\nu}}$, T. SABRINA \\ Faculty of Agriculture, Universitas Sumatera Utara. Jl. Prof. A. Sofyan No.3, Padang Bulan, Medan 20155, North Sumatra, Indonesia. \\ Tel.: +62-61-8213236, •email: mariani.sembiring29@yahoo.com; marianisembiring@usu.ac.id
}

Manuscript received: 15 May 2021. Revision accepted: 29 July 2021.

\begin{abstract}
Sembiribg M, Sabrina T. 2021. Diversity of non-symbiotic nitrogen-fixing bacteria and their potential in andisols affected by the eruption of Mount Sinabung, North Sumatra, Indonesia. Biodiversitas 22: 3539-3544. Nitrogen is the main macro-nutrient that is very important for plant growth. Nitrogen is absorbed by plants in the form of $\mathrm{NO}^{3-}$ or $\mathrm{NH}^{4+}$ ions from the soil. The andisols affected by the eruption of Mount Sinabung alter the chemical, physical and biological characteristics of the soil. As a result, the population of beneficial microbes in the soil decreased, so soil fertility also decreased. The aim of this research is to determine the diversity of nitrogen-fixing microbes in andisol soil affected by the Mt. Sinabung eruption. The soil samples used in this research were collected from andisols affected by the eruption of Mount Sinabung. The isolation of non-symbiotic nitrogen-fixing bacteria was carried out using a nitrogen-free Jensen medium. The results showed that five non symbiotic $\mathrm{N}$-fixing bacteria can increase the $\mathrm{N}$ content in andisols affected by Mount Sinabung eruption. Enterobacter cloacae can increase soil $\mathrm{N}$ by $111.76 \%$ as compared to without microbial application.
\end{abstract}

Keywords: Andisols, nitrogen-fixing bacteria, soil N, diversity, N fixation

\section{INTRODUCTION}

Nitrogen is a nutrient that is easily washed and evaporates, hence its availability in the soil decreases, while its amount in the atmosphere increases. One way to increase the availability of $\mathrm{N}$ in the soil is by utilizing environmentally specific nitrogen-fixing microbes. Volcanic ash contains heavy metals and harmful microsubstances which are easy to settle. The volcanic ash that covers the surface over a long period of time settles and hardens. Depending on the thickness levels, ash deposited causes disturbance in soil aeration, which affects microorganisms in the soil. The thicker the volcanic ash, the fewer microorganisms in the soil (Pakolo et al. 2018; Sarah et al. 2015; Munawaroh et al. 2020; Qadaryanty et al. 2020; Zebua et al. 2020)

The $\mathrm{pH}$ of soil greatly influences the growth of soil microorganisms. Fungi can tolerate and survive a soil $\mathrm{pH}$ range of 4-6.5, while bacteria prefer a soil $\mathrm{pH}$ of 6 to 7 (Hanafiah et al. 2009). According to Sinaga et al. (2014) the thicker the ash, the lower the $\mathrm{pH}$ of soil. Volcanic ash contains heavy metals and harmful micro-substances which are easily deposited. The $\mathrm{pH}$ of Mount Sinabung volcanic ash ranged from 3.3 to 3.5 , while the soil $\mathrm{pH}$ ranged from 4.4 to 6.5 which inhibited the activity of soil organisms (Balitbangtan 2014; Fatmala et al. 2015; Sinaga et al. 2015; Sembiring and Fauzi 2017; Sembiring et al. 2017b) The eruption of Mount Sinabung reduced organic matter in the soil hence nitrogen content in the soil was low. This happens because exposure to the ash makes it difficult for soil organisms to survive, disrupting the decomposition process (Sinaga et al. 2015). N-total in soil was affected by volcanic ash ranged from very low to low $0.04 \%-0.20 \%$ (Sembiring et al. 2017a; Sembiring et al. 2017b). Sembiring et al. (2016) reported showed that total Corganic and $\mathrm{N}$ content in the soil affected by the eruption was $5.74 \%$ and $0.56 \%$. This is because the source of nitrogen in the soil is reduced, and the microorganisms that function to fix nitrogen in the air are also reduced (Hanafiah 2014). Nitrogen (N) is one of the most widely distributed elements in nature. The problem in terms of the availability of $\mathrm{N}$ in the soil is the nature of nitrogen as it is easily dissolved or washed and evaporated by which the amount in the soil is reduced while the amount in the atmosphere is high. Nitrogen fixation can be of two types namely, symbiotic or non-symbiotic. Microorganisms that play a role in non symbiotic fixation include Azospirillum, Azotobacter, and Beijerincka (active in acid soil conditions), Bacillus, Enterobacter, etc (Hanafiah 2014).

\section{MATERIALS AND METHODS}

The soil used in this research was taken from andisols affected by the eruption of Mount Sinabung, from the Naman Teran Sub-district, Karo District, North Sumatra Province, Indonesia. The research was carried out from June to December 2020.

\section{Sampling}

Sampling points were taken from the soil which was distinguished based on several ash thicknesses, i.e. 
Location $\mathrm{I}=$ cultivated land $(0 \mathrm{~cm})$, Location $\mathrm{II}=$ soil with $<2 \mathrm{~cm}$ ash thickness, Location III = soil with medium ash thickness $(2-5 \mathrm{~cm})$, and Location IV = soil with thick ash thickness $(>5 \mathrm{~cm})$. The samples were taken at a depth of 0 $20 \mathrm{~cm}$ from the soil surface around the rhizosphere area using a hoe. Eight soil samples were taken from each location, which was then composited. Soil temperature and humidity were also recorded in the field at the time of soil sampling. The soil samples were then brought to the laboratory for initial analysis such as Temperature $\left({ }^{\circ} \mathrm{C}\right)$, Humidity (\%), pH (electrometry), C-Organic (Walkley and Black), S-Dissolved (Turbidimetry), N-Total (Kjeldahl), and total microbes (Plate Count Method) analysis.

\section{Isolation and identification of bacteria}

The Jensen media was used for the isolation of bacteria and the composition of media was as follows: (Sucrose $20 \mathrm{~g}, \mathrm{~K} 2 \mathrm{HPO} 4 \mathrm{~g}, \mathrm{MgSO} 4.7 \mathrm{H} 2 \mathrm{O}$ 0.5g, NaCL 0.5g, FeSO4 $0.1 \mathrm{~g}, \mathrm{CaCO} 32 \mathrm{~g}$, jelly $20 \mathrm{~g}$, aquadest $1 \mathrm{~L})$. Ingredients used for gram staining include crystal violet solution, iodine solution, $70 \%$ alcohol solution, safranin solution.

To obtain nitrogen-fixing bacteria present at the four observation sites, soil bacteria were isolated by multilevel dilution and using the pour plate method. The first step was to take soil from several locations with different thicknesses of ash and then compost it (mixed). Take $10 \mathrm{~g}$ of composite soil in a beaker, add $90 \mathrm{~mL}$ of sterile distilled water to it, and then homogenize it using a shaker. Furthermore, a dilution technique was carried out on soil suspension, to make a dilution factor of 10-1 to 10-5, take 1 $\mathrm{mL}$ of the sample suspension and mix it with $9 \mathrm{~mL}$ of distilled water (10-1). Then $1 \mathrm{~mL}$ of suspension was pipette out from first dilution factor (10-1) and added to $9 \mathrm{~mL}$ of distilled water (10-2), the same treatment was done for rest of the dilution factors (10-3, 10-4, and 10-5). $1 \mathrm{~mL}$ of each dilution factor (10-3, 10-4 and 10-5) was poured into the Petridish, then add $20 \mathrm{~mL}$ of Jensen medium, mix well and incubated at $30^{\circ} \mathrm{C}$ for $72 \mathrm{~h}$. After the colony grew, isolated species were identified based on morphological and molecular levels. To identify bacteria at the molecular level, universal primers of 63f (5'CAG GCC TAA CAC ATG CAA GTC 3'), primer 1387r (5' GGG CGG WGT GTA CAA GGC 3') were used to amplify the gene sequence of 16S bacteria rRNA through PCR (Lane 1991).

\section{Potential test of nonsymbiotic fixing bacteria on andisols}

The soil used to test the potential of microbes in fixing nitrogen was andisol soil taken from location II which was covered with thin ash $(<2 \mathrm{~cm}) .50 \mathrm{~g}$ of sterilized soil was prepared, then $1 \mathrm{~mL}\left(10^{8}\right)$ was mixed with media and incubated for 30 days at room temperature. The parameters observed after the incubation process were: $\mathrm{pH}$ (electrometry), N-Total (Kjeldahl), and total microbes (Plate Count Method). The calculation of the bacterial population in the medium was calculated using the formula:

Total Bacteria $=\sum$ Colony $\mathrm{x}$ Diluting factor

\section{RESULTS AND DISCUSSION}

\section{Analysis of soil conditions at several thicknesses of eruption ash}

Based on the results of the initial analysis temperature, humidity, soil $\mathrm{pH}$, organic $\mathrm{C}, \mathrm{N}, \mathrm{S}$, and microbial populations were found to be different at each observation location (Table 1).

The result showed that thicker the volcanic ash covering the soil increased temperature by $31.58 \%$ (Location IV), while decreased soil moisture by $36.67 \%$. This indicated that thicker the volcanic ash which covered the soil surface, inhibited aeration and infiltration into the soil. The highest 5.8-6.2 soil $\mathrm{pH}$ was recorded from (Location I), and the lowest $3.5 \mathrm{pH}$ was at location IV. The decrease in $\mathrm{pH}$ with increasing ash thickness was $77.14 \%$ (Location IV). The thicker the volcanic ash, the lower the $\mathrm{pH}$ value of the soil. This is because the volcanic ash of Mount Sinabung was dominated by high sulfur content which causes a decrease in pH. Simanjuntak et al. (2015) stated that the factor that affects soil $\mathrm{pH}$ is the high sulfur (S) content in volcanic ash, resulting in a very acidic to acidic soil pH. Sembiring et al. (2015) reported that the $\mathrm{pH}$ of volcanic ash from the eruption of Mount Sinabung is very acidic (3.3-3.5), this acidic nature of volcanic ash can affect the physical, chemical and biological properties of the soil. The highest S-dissolved was $0.34 \%$ at Location IV and the lowest was $0.09 \%$ at location I. This indicates that the thicker the volcanic ash on andisol soil, the higher the S-dissolved content. This occurs because volcanic ash contains quite high sulfur, and rainfall also affects the $S$ content in the volcanic ash of Mount Sinabung. Sulfur leached to the soil layer below by the rain, which resulted in $\mathrm{S}$ in the soil mixed with volcanic ash. According to Balitbangtan (2014), Mt. Sinabung volcanic ash is containing $\mathrm{S}$ elements ranged from $0.05-0.32 \%$. The high sulfur content in volcanic ash affects soil $\mathrm{pH}$.

Table 1. Soil conditions at each sampling location

\begin{tabular}{lccccccc}
\hline $\begin{array}{l}\text { Sampling } \\
\text { location }\end{array}$ & $\begin{array}{c}\text { Temperature } \\
(\mathbf{C})\end{array}$ & $\begin{array}{c}\text { Humidity } \\
(\mathbf{\%})\end{array}$ & $\mathbf{p H}$ & $\begin{array}{c}\mathbf{C} \text { Organic } \\
(\boldsymbol{\%})\end{array}$ & $\mathbf{N}(\boldsymbol{\%})$ & $\begin{array}{c}\text { S dissolved } \\
(\boldsymbol{\%})\end{array}$ & $\begin{array}{c}\text { Microbial } \\
\text { population }\left(\mathbf{1 0} \mathbf{4}^{\mathbf{4}}\right)\end{array}$ \\
\hline I & $19-20$ & $78-82$ & $5.8-6.2$ & $6.29-7.45$ & $0.55-0.65$ & $0.09-0.15$ & $25-33$ \\
II & $19-21$ & $77-78$ & $5.5-5.8$ & $2.47-5.01$ & $0.20-0.33$ & $0.08-0.12$ & $18-26$ \\
III & $22-24$ & $70-72$ & $3.8-4.5$ & $1.30-1.87$ & $0.09-0.19$ & $0.09-0.18$ & $9-12$ \\
IV & $24-25$ & $60-68$ & $3.5-4.3$ & $0.65-1.18$ & $0.07-0.11$ & $0.21-0.34$ & $4-6$ \\
\hline
\end{tabular}

Note: Location I: Cultivated land $(0 \mathrm{~cm})$, II: soil with $<2 \mathrm{~cm}$ ash thickness, III: soil with medium ash thickness $(2-5 \mathrm{~cm})$, IV: soil with thick ash thickness $(>5 \mathrm{~cm})$ 
The highest $(7.45 \%) \mathrm{C}$ organic content was found at Location I, and the lowest $(0.65 \%)$ was at Location IV. It was also noted that the $\mathrm{C}$ organic content decreased with an increase of ash thickness by $104.62 \%$. According to Sukarman and Dariah (2014), the C-organic content of andisol soil found in Indonesia varies from very low to very high. Simanjunak et al. (2015) mentioned that Corganic soil affected by the Mt. Sinabung eruption ranged from $0.91 \%-7.19 \%$. Sinaga et al. (2015) stated that volcanic ash that covers the soil surface settle down and harden depending on its thickness level. It affects soil aeration, respiration, oxygen, and organic matter availability in the soil, affecting the life of organisms in the soil.

The highest N-total soil was at Location I by $7.45 \%$ and the lowest was at Location IV by $0.07 \%$. It was also noted that increasing ash thickness by $105.43 \%$ decreased the $\mathrm{N}$ total in the soil. Soil nitrogen value is influenced by soil's organic matter and microorganisms that fix $\mathrm{N}$ from the air. This follows the work of Sinaga et al. (2015), which noted that the thickness of volcanic ash covering the soil makes it difficult for plant roots to penetrate in the soil and soil organisms are difficult to survive hence the decomposition process is hampered. Simanjuntak et al. (2015) mentioned that the soil mixed with ash with a depth of 5-20 cm has a nitrogen value ranging from very low to low, i.e. $0.04 \%$ $0.20 \%$. Increases in soil temperature and the decreases in $\mathrm{pH}$, humidity and soil $\mathrm{C}$ organic affect the population of organisms in the soil. The microbial population at location IV decreased by $72.5 \%$ compared to location I. This indicates that environmental conditions greatly affect the number and activity of organisms in the soil. According to Tindaon et al (2016), the amount of sulfur and $\mathrm{Al}$ in the soil greatly affects the soil $\mathrm{pH}$, affecting the number of organisms in the soil. The low $\mathrm{pH}$ results in disruption of the activities in soil organisms (Hanafiah 2014).

\section{Isolation and identification of bacteria}

Results showed that from the 4 locations observed, 5 bacteria isolates of had different colony characteristics, namely N1 from location I, N2 and N3 from location II, N4 from Location III and N5 from Location IV.

The differences in the composition of the nucleotides that make up the 16S rRNA coding DNA for each isolate were different, so a kinship analysis was carried out using the BLAST (Basic Local Alignment Search Tool) program. The results of molecular identification of 5 bacterial isolates coded N1, N2, N3, N4 and N5 are presented in Figure 1.

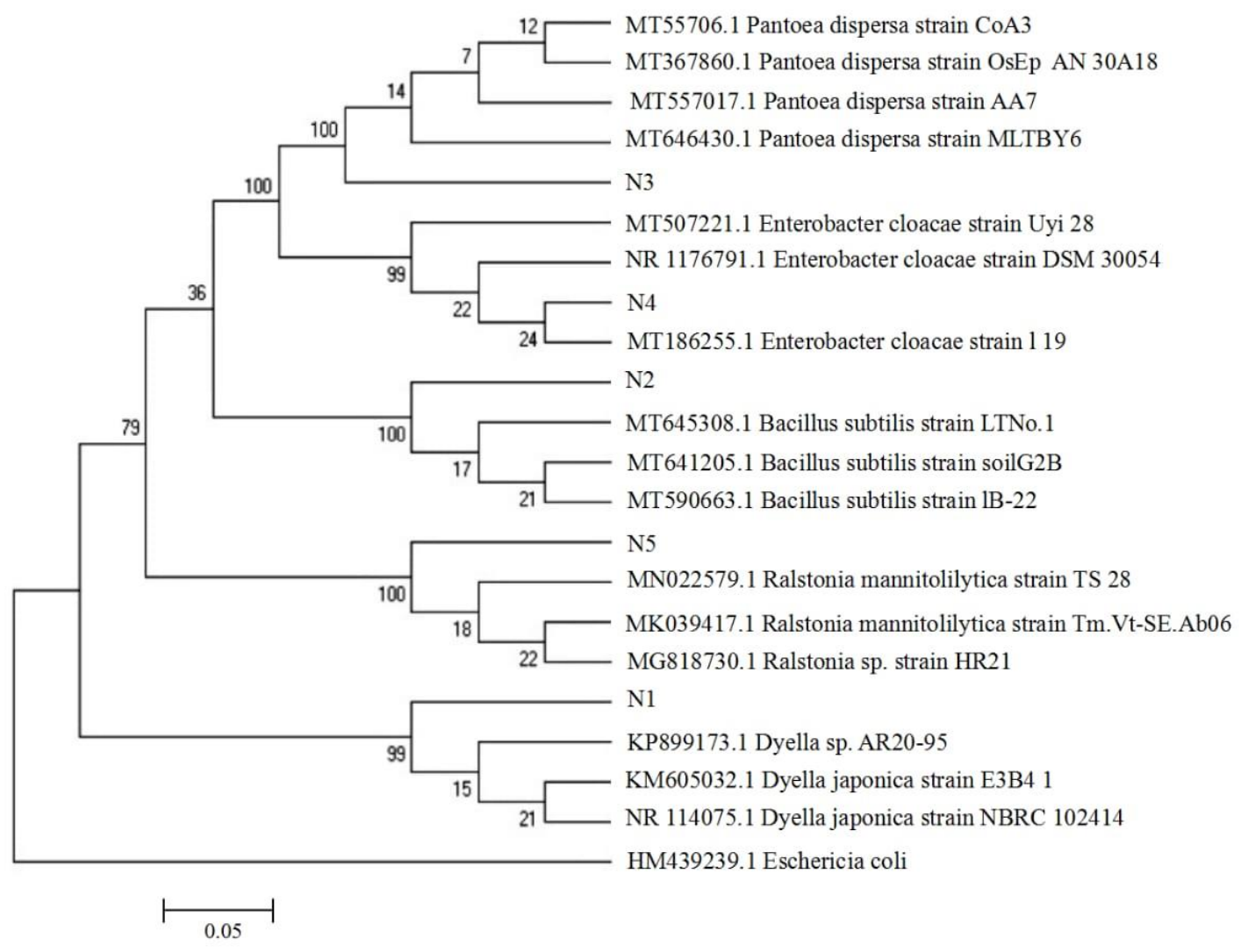

Figure 1. Phylogeny tree of non-symbiotic nitrogen-fixing bacteria sourced from andisols affected by the Mt. Sinabung eruption, North Sumatra, Indonesia 
The results of the kinship analysis with the BLAST program were then continued with phylogenetic tree analysis. Based on the identification results (Figure 1), a 16S rDNA sequence showed that the N1 strain was Dyella japonica, N2 was Bacillus subtilis, N3 was Pantoea dispersa, N4 was Enterobacter cloacae, and N5 was Ralstonia mannitolilytica. The results of research by Xie and Yokota, 2005, found that D. japonica is a Gramnegative bacterium capable of fixing $\mathrm{N}$ from the air and requires a $\mathrm{pH}$ of 6.5-7 and optimum temperature of 25 $30^{\circ} \mathrm{C}$. B. subtilis fixed nitrogen from the air and its growth decrease at high salt contents (Delgado et al. 1994; Satapute et al. 2012; Jesmi et al. 2017). B. subtilis is able to survive at a $\mathrm{pH}$ of 5.0-10 and the optimum $\mathrm{pH}$ for growth is 7-7.5 (Jadhav et al. 2010). B. subtilis able to produce IAA and stimulate plant growth (Salamone et al. 2001; Karadeniz et al. 2006; Ahmad et al. 2016). P. dispersa is a PGPR that can increase plant growth in soil conditions with high salinity (Habib et al. 2016; Panwar et al. 2016). P. dispersa is a bacterium capable of producing IAA and $\mathrm{P}$ solvent in soil (Deshwal and Kumar 2013; Paul et al. 2014). Ji et al. (2010) and Liu et al. (2017) found that $E$. cloacae is a bacterium that can increase nitrogen fixation and increase plant growth. $R$. mannitolilytica is a bacterium capable of fixing nitrogen and dissolving phosphate, especially in land contaminated with heavy metals (Paul and Datta 2016).

Each species of bacteria has different morphological characteristics from one species to another. The difference in these characters can be used as a guide to finding out the taxonomic position. Based on Figure 2, all bacteria cell form was different, which showed that the types of bacteria were also different. The data obtained are consistent with some of the morphological data of nitrogen-fixing bacteria reported in previous studies by Hartono 2014; Xie and Yokota 2005 bacteria that can fix $\mathrm{N}$ are generally gramnegative and round cells. This is in accordance with the result of Santoso et al. (2019) that 3 bacterial isolates that namely Azotobacter, Azospirillum and Pseudomonas can freely fix $\mathrm{N}$, all being gram-negative and round cells.

The potential test results showed that nitrogen-fixing bacteria can increase $\mathrm{N}$ in the soil Enterobacter cloacae (N4) and increase soil $\mathrm{N}$ by $111.76 \%$ compared to without microbial application (Table 2). R. mannitolilytica bacteria can increase soil $\mathrm{N}$ by $11.76 \%$, this shows that the application of nitrogen-fixing microbes at acidic soil $\mathrm{pH}$ can increase $\mathrm{N}$ content in the soil. The ability of nitrogenfixing microbes to fix $\mathrm{N}$ varies depending on their ability to adapt to their environment. The $\mathrm{pH}$ of soil used was ranged from 5.07-5.42 which indicated that the $\mathrm{pH}$ was very acidic hence it inhibited the growth and activity of bacteria in the soil. According to Xie and Yokota (2005); Jadhav et al. (2010), 6.6-10 is the optimum $\mathrm{pH}$ for bacterial growth and its activity in fixing nitrogen from the air. The results showed that the ability of microbes to survive in the soil used was different depending on the type of bacteria. $B$. subtilis $\left(25.50 \times 10^{8}\right)$ has a higher survival rate than other bacteria. This is because the soil $\mathrm{pH}$ is close to the optimum $\mathrm{pH}$ of 5.42. The growth of microorganisms in the soil is strongly influenced by soil $\mathrm{pH}$. Bacteria can survive at neutral $\mathrm{pH}(6-7)$ and their activity decreases if the $\mathrm{pH}$ is too low (Hanafiah et al. 2009).
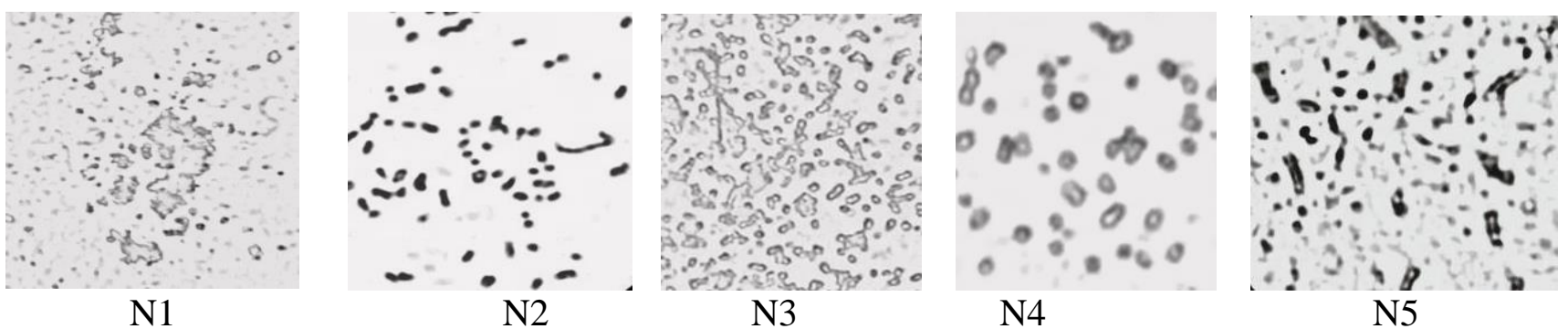

Figure 2. The bacterial cell form of N1. Dyella japonica, N2. Bacillus subtilis, N3. Pantoea dispersa, N4. Enterobacter cloacae, and N5. Ralstonia mannitolilytica

Table 2. Potential test for nitrogen-fixing bacteria to increase soil $\mathrm{N}$ content

\begin{tabular}{lcccc}
\hline Treatment & Soil $\mathbf{~ H H}$ & Soil N $(\boldsymbol{\%})$ & Microbial population $\left(\mathbf{1 0}^{\mathbf{8}}\right)$ & IAA \\
\hline Without Microbes (N0) & 5.29 & 0.17 & 0.00 & - \\
Dyella japonica (N1) & 5.31 & 0.24 & 20.00 & 1.05 \\
Bacillus subtilis (N2) & 5.42 & 0.29 & 25.50 & 1.01 \\
Pantoea dispersa (N3) & 5.07 & 0.21 & 12.50 & 0.65 \\
Enterobacter cloacae (N4) & 5.24 & 0.36 & 24.00 & 2.65 \\
Ralstonia mannitolilytica (N5) & 5.26 & 0.19 & 24.50 & 2.45 \\
\hline
\end{tabular}


The results of the analysis showed that the microbes found were able to produce IAA up to $0.65-2.65 \mathrm{ppm}$ indicating that the ability of microbes to fix $\mathrm{N}$ and stimulate plant growth would be different. E. cloacae has a higher IAA content when compared to other microbes, this indicates that $E$. cloacae has a higher $\mathrm{N}$ fixing ability. $E$. cloacae has a high nitrogen fixation activity, and can be found in the plant rhizosphere (Wang et al. 2012; MacedoRaygoza et al. 2019; Li et al. 2017). According to the results of Liu et al. (2017), E. cloacae can increase nitrogen fixation hence plant growth increases. E. cloacae application can increase plant growth and affect soil ecology (Kumaran et al. 2010; Ramesh et al. 2014; Khalifa et al. 2016). Nitrogen-fixing microbes can stimulate plant growth and fix nitrogen from the air in high amounts (Paul and Lade 2014; Nabti et al. 2015; Shrivastava and Kumar 2015).

It is concluded that five non-symbiotic $\mathrm{N}$-fixing bacteria were isolated, which increased the $\mathrm{N}$ content in andisols affected by the eruption of Mount Sinabung. Enterobacter cloacae can increase soil N by $111.76 \%$ compared to without microbial application.

\section{ACKNOWLEDGEMENTS}

The author would like to thank the Directorate General of Research and Development Strengthening of the Ministry of Research, Technology and Higher Education of the Republic of Indonesia, for providing research funding in 11/AMD/EI/KP.PTNBH/2020 research. The author also thanks the Universitas Sumatera Utara, Indonesia for providing facilities to conduct research.

\section{REFERENCES}

Ahmad I, Akhtar MJ, Asghar HN, Ghafoor U, Shahid M. 2016 Differential effects of plant growth-promoting rhizobacteria on maize growth and cadmium uptake. J Plant Growth Regul 35: 303-315. DOI: $10.1007 / \mathrm{s} 00344-015-9534-5$

Balitbangtan. 2014. Tanah Andosol di Indonesia karakteristik, potensi, kendala, dan pengelolaannya untuk pertanian. Badan Penelitian dan Pengembangan Pertanian, Jakarta. [Indonesian]

Delgado MJ, Ligero F and Lluch C. 1994. Effects of salt stress on growth and nitrogen fixation bypea, faba-bean, common bean and soybean plants. Soil Biol Biochem 26 (3): 371-376. DOI: 10.1016/00380717(94)90286-0

Deshwal V, Kumar P. 2013. Effect of salinity on growth and PGPR activity of Pseudomonads. J Acad Ind Res 2 (6): 353-356

Fatmala V, Sembiring M, Jamilah. 2015. Eksplorasi jamur pelarut fosfat pada Andisol terkena dampak erupsi Gunung Sinabung dengan beberapa ketebalan abu di Kecamatan Naman Teran Kabupaten Karo. Jurnal Online Agroekoteknologi 3 (3):1164-1168. [Indonesian]

Habib SH, Kausar H, Saud HM. 2016. Plant growth-promoting rhizobacteria enhance salinity stress tolerance in okra through ROSscavenging enzymes. Biomed Res Intl 2016: 6284547. DOI: $10.1155 / 2016 / 6284547$

Hanafiah AS, Sabrina T, Guchi H. 2009. Biologi dan ekologi tanah. USU Press, Medan. Indonesia. [Indonesian]

Hanafiah KA. 2014. Dasar-dasar ilmu tanah. PT. Raja Grafindo Persada, Jakarta. [Indonesian]

Hartono, Jumadi O. 2014. Seleksi dan karakteristik bakteri penambat nitrogen non simbiotik pengekskresi amonium pada tanah pertanaman jagung (Zea mays L.) dan padi (Oryza sativa L.) asal Kabupaten
Barru, Sulawesi Selatan, Indonesia. Jurnal Sainsmat 3 (2): 143-153. DOI: 10.35580/sainsmat3211222014. [Indonesian]

Jadhav GG, Salunkhe DS, Nerkar DP, Bhadekar RK. 2010. Isolation and characterization of salt-tolerant nitrogen-fixing microorganisms from food. J Eur Asia Biol Sci 4 (1): 33-40. DOI: 10.5053/ejobios.2010.4.0.5

Jesmi Y, Thajudeen J, Rahiman M, Krishnankutty S, Aneesa P, Alikunj, Abdulla MHA. 2017. Nitrogen-fixing potential of various heterotrophic Bacillus strains from a tropical estuary and adjacent coastal regions. J Basic Microbiol 57 (11): 922-932. DOI: 10.1002/jobm.201700072.

Ji C, Liu Z, Hao L, Song X, Wang C, Liu Y, Li H, Li C, Gao Q, Liu X. 2020. Effects of Enterobacter cloacae HG-1 on the nitrogen-fixing community structure of wheat rhizosphere soil and on salt tolerance. Front Plant Sci 11:1094. DOI: 10.3389/fpls.2020.01094.

Karadeniz A, Topcuoglu S, Inan S. 2006. Auxin, gibberellin, cytokinin and abscisic acid production in some bacteria. World $\mathrm{J}$ Microbiol Biotechnol 22: 1061-1064. DOI: 10.1007/s11274-005-4561-1.

Kumaran D, Dastager S, Pandey A. 2010. Isolation and characterization of plant growth-promoting bacteria from non-rhizospheric soil and their effect on cowpea (Vigna unguiculata L.) Walp. seedling growth. World J Microbiol Biotechnol. 26: 1233-1240. DOI: 10.1007/s11274009-0293-y.

Khalifa AYZ, Alsyeeh AM, Almalki MA, Saleh FA. 2016. Characterization of the plant growth-promoting bacterium, Enterobacter cloacae MSR1, isolated from roots of non-nodulating Medicago sativa. Saudi J Biol Sci 23 (1): 79-86. DOI: 10.1016/j.sjbs.2015.06.008

Lane DJ. 1991. 16S/23S rRNA Sequencing. In: Stackebrandt E, Goodfellow M (eds). Nucleic Acid Techniques in Bacterial Systematics. John Wiley and Sons, New York.

Li H, Lei P, Pang X, Li S, Hong, Xu, 2017. Enhanced tolerance to salt stress in canola (Brassica napus L.) seedlings inoculated with the halotolerant Enterobacter cloacae HSNJ4. Appl Soil Ecol 119: 26-34. DOI: 10.1016/j.apsoil.2017.05.033.

Liu X, Li X, Yan L, Li R, Xie Z. 2017. Plant growth promotion properties of bacterial strains isolated from the rhizosphere of the Jerusalem artichoke (Helianthus tuberosus L.) adapted to saline-alkaline soils and their effect on wheat growth. Can J Microbiol 63: 228-237. DOI: 10.1139/cjm-2016-0511.

Macedo-Raygoza GM, Valdez-Salas, B, Prado FM, Yamaguchi LF, Prieto KR. 2019. Enterobacter cloacae, an endophyte that establishes a nutrient-transfer symbiosis with banana plants and protects against the black Sigatoka pathogen. Front Microbiol 10: 804 DOI: 10.3389/fmicb.2019.00804.

Munawaroh H, Sembiring M, Hanafiah AS. 2020. Identification of macrofauna on various volcanic ash thickness and different vegetation in andisol affected by Sinabung eruption. IOP Conf Ser: Earth Environ Sci 454: 012091. DOI: 10.1088/1755-1315/454/1/012091.

Nabti E, Schmid M, Hartmann A. 2015. Application of halotolerant bacteria to restore plant growth under salt stress. Springer, Cham. DOI: 10.1007/978-3-319-14595-2_9.

Pakolo N, Sembiring M, Rauf A. 2018. Isolasi dan uji potensi mikroorganisme pelarut posfat pada Andisol terdampak erupsi Sinabung pada bebrapa ketebalan abu di Kabupaten Karo. Jurnal Pertanian Tropik 5 (3):-

Panwar M, Rupinder Tewari, Harsh Nayyar. 2016. Native halotolerant plant growth-promoting rhizobacteria Enterococcus and Pantoea $s p$. improve seed yield of Mungbean (Vigna radiata L.) under soil salinity by reducing sodium uptake and stress injury. Physiol Mol Biol Plants. 22 (4): 445-459. DOI 10.1007/s12298-016-0376-9

Paul S, Aggarwal C, Thakur JK, Rathi MS. 2014. Effect of salt on growth and plant growth-promoting activities of Azotobacter chroococcum isolated from saline soils. Environ Ecol 32: 1255-1259.

Paul D, Lade H. 2014. Plant growth-promoting rhizobacteria to improve crop growth in saline soils: A review. Agron Sustain Dev 34 (4): 737 752. DOI: $10.1007 / \mathrm{s} 13593-014-0233-6$

Paul A, Datta B. 2016. Cadmium-resistant Ralstonia mannitolilytica relieved Cadmium toxicity in mustard plants through root colonization and growth-promoting activity. Res J Microbiol 11 (6): 157-168.

Qadaryanty I, Sembiring M, Hidayat B. 2020. Various impacts of Sinabung eruption volcanic ash thickness with different vegetation on the microorganism population in andisols. IOP Conf Ser: Earth Environ Sci 454: 012168 DOI:10.1088/1755-1315/454/1/012168. 
Ramesh A, Sharma S, Sharma M, Yadav N, Joshi O. 2014. Plant growthpromoting traits in Enterobacter cloacae subsp. dissolvens MDSR9 isolated from soybean rhizosphere and its impact on growth and nutrition of soybean and wheat upon inoculation. Agric Res 3: 53-66. DOI: $10.1007 /$ s40003-014-0100-3.

Salamone GD, Russell K Hynes, and Nelson LM. 2001. Cytokinin production by plant growth-promoting rhizobacteria and selected mutants. Can J Microbiol 47 (5): 404-411.

Santoso K, Rahmawati, Rafdinal. 2019. Eksplorasi bakteri penambat nitrogen dari tanah hutan mangrove Sungai Peniti, Kabupaten Mempawah. Jurnal Protobiont 8 (1): 52-58. [Indonesian]

Satapute PP, Olekar HS, Shetti AA, Kulkarni AG, Hiremath GB, Patagundi BI, Shivsharan CT, Kaliwal BB. 2012. Isolation and characterization of nitrogen-fixing Bacillus subtilis strain as-4 from agricultural soil. Intl J Re Sci Res 3 (9): 762-765.

Sarah P, Elfiati D, Delvian. 2015. Aktivitas mikroorganisme pada tanah bekas erupsi Gunung Sinabung di Kabupaten Karo. Peronema Fore Sci J 4 (4): 1-6 [Indonesian]

Sembiring M, Elfiati D, Sutarta ES, Sabrina T. 2016. Effect of Burkholderia cepacia and SP36 on available phosphate and potato production on Andisol impacted by mount Sinabung eruption, North Sumatera, Indonesia. J Appl Horticult 18 (3): 233-235.

Sembiring M, Fauzi. 2017. Bacterial and Fungi phosphate solubilization effect to increase nutrient uptake and potatoes (Solanum tuberosum L.) production on Andisol Sinabung area. J Agro 16 (3): 131-137. DOI: $10.3923 /$ ja.2017.131.137

Sembiring M, Elfiati D, Sutarta ES, Sabrina T. 2017a. Phosphate solubilization agents in increasing potatoes production on Andisol Sinabung area. Asian J Pl Sci 16 (3): 141-148. DOI: 10.3923/ajps.2017.141.148.

Sembiring M, Alifa S, Bintang. 2017b. Phosphate fertilization efficiency through the use of microbial phosphate solubilization to boost growth of mustard (Brassica juncea L.) in Andisol affected by Sinabung eruption. J Appl Hort 19 (3): 196-19.

Shrivastava P, Kumar R. 2015. Soil salinity: A serious environmental issue and plant growth-promoting bacteria as one of the tools for its alleviation. Saudi J Biol Sci 22 (2): 123-131. DOI: 10.1016/j.sjbs.2014.12.001.

Sinaga B, Sembiring M, Lubis A. 2015. Dampak ketebalan abu vulkanik erupsi Gunung Sinabung terhadap sifat biologi tanah di Kecamatan Naman Teran Kabupaten Karo. Jurnal Agroekoteknologi 3 (3): 11591163. [Indonesian]

Simanjuntak CM, Elfiati D, Delvian. 2015. Dampak Erupsi Gunung Sinabung Terhadap Sifat Kimia Tanah Di Kabupaten Karo. Peronema For Sci J 4 (4): 53-55. [Indonesian]

Sukarman, Dariah A. 2014. Tanah Andisol di Indonesia. Balai Besar Penelitian dan Pengembangan Sumberdaya Lahan Pertanian, Bogor. [Indonesian]

Tindaon F, Tampubolon B, Lumbanraja P. 2016. Komposisi kimia abu erupsi Gunung Sinabung Tanah Karo dan Lumpur Vulkanik Sidoarjo Jawa TImur. Prosiding Seminar Nasional BKS PTN Wilayah Barat Bidang Ilmu Pertanian 2016, Lhokseumawe, 5-6 Agustus 2016.

Wang YG, Xia QY, Gu WL, Sun JB, Zhang H, Lu XH. 2012. Isolation of a strong promoter fragment from endophytic Enterobacter cloacae and verification of its promoter activity when its host strain colonizes banana plants. Appl Microbiol Biotechnol 93 (4): 1585-1599. DOI: 10.1007/s00253-011-3684-6.

Xie $\mathrm{CH}$, Yokota A. 2005. Dyella japonica gen. nov., sp. nov., a $\gamma$ proteobacterium isolated from soil. Intl J Syst Evol Microbiol. 55 (Pt 2): 753-756 DOI: 10.1099/ijs.0.63377-0.

Zebua AC, Guchi H, Sembiring M. 2020. Isolation of non-symbiotic Nitrogen-fixing bacteria on andisol land affected by Sinabung eruption. IOP Conf Ser: Earth Environ Sci 454: 012167. DOI: 10.1088/1755-1315/454/1/012167. 